\title{
Evaluation of Heavy Metals Level and Proximate Analysis of Common Fruits from Selected Markets in Lagos, Nigeria
}

\section{ROTIMI, OT; OGUNYEBI, AL; *FINGESI, TS}

\author{
Department of Cell Biology and Genetics, Faculty of Science, University of Lagos, Akoka, Nigeria \\ *Corresponding Author Email: justinafingesi@yahoo.com
}

\begin{abstract}
This study was carried out to determine the heavy metals concentration and proximate composition of five different fruits collected in triplicates from five different markets in five local government areas of Lagos state in Nigeria and extracted using Double Acid Extraction Method. Heavy metals concentration was performed using Atomic Absorption Spectrophotometer and proximate composition was determined by Association of Official Analytical Chemistry (AOAC) method. Results showed that the highest level of lead was found in carrot $(0.18 \pm 0.7)$ while pineapple $(0.10 \pm 0.0)$ had the lowest level of lead. The fruits in this study may have been polluted with lead through pollutants in irrigation water, farm soil or due to pollution from the highway traffic. Chromium, Cadmium and Copper was observed to be low in all the fruits analyzed, which is still within the safe limit set by FAO/WHO. Zinc had the highest concentration $(3.99 \pm 0.8)$ in water melon; proximate analysis indicated significant variability in the constituents contained in the fruits studied (moisture content, carbohydrate and crude fat in descending order). The highest moisture content was found in watermelon (91.3\%) and the highest crude protein in carrot (1.138\%). The concentrations of the toxic heavy metals are within the tolerable limits of some regulatory authorities. However, there is need for continuous monitoring of heavy metals and proximate analysis in fruits because, fruits are the main sources of food supplements for humans in many parts of the world and are considered as bio-indicators of environmental pollution.
\end{abstract}

\section{DOI: https://dx.doi.org/10.4314/jasem.v22i5.34}

Copyright: Copyright $\left({ }_{0} 2018\right.$ Rotimi et al. This is an open access article distributed under the Creative Commons Attribution License (CCL), which permits unrestricted use, distribution, and reproduction in any medium, provided the original work is properly cited.

Dates: Received: 07 April 2018; Revised: 19 April: 2018; Accepted: 22 April 2018

Keywords: Heavy metals, analysis, fruits, food quality

The safety and quality of the foods and fruits we eat have created a global concern. The World Health Organization (WHO) defines "Food Safety" as the absence or presence of acceptable and safe levels of contaminants, adulterants, naturally-occurring toxins or any other substance that may make food injurious to health on an acute or chronic basis (Abbas et al., 2010). Fresh fruits are very important protective food, useful for the maintenance of health as well as the prevention and treatment of various diseases (Mausi et al., 2014). Inadequate intake of fruits is rapidly becoming recognized as one of the key risk factors for the two leading causes of death in the world today namely: cardiovascular diseases and some forms of cancers (WHO, 2012). However, fruits have been reported to contain both essential and toxic metals over a wide range of concentrations (Sobukola et al., 2008). Heavy metals are natural constituents of the Earth's crust; they are stable and are non-biodegradable, therefore they tend to accumulate in soils and sediments (Jassir et al., 2005). Heavy metals are mobile and easily taken up by plants in the environment. However, plants have shown a great ability to accumulate metals from the environment
(Khairiah et al., 2004). The bio toxic effects of heavy metals cannot be over-emphasized. Although individual metals exhibit specific signs of their toxicity; Cadmium, Lead, Copper, Mercury, Zinc, Arsenic poisoning are associated with gastrointestinal disorders, diarrhea, stomatitis, heamoglobinuria, pneumonia, ataxia etc (Elgbagermi et al., 2012). Also, the nature of their effects could be neurotoxic, carcinogenic, mutagenic or teratogenic (Pasha et al., 2010). Trace elements do not provide any calorie to the body but they play an essential role in the metabolic regulations of the human body if present in required amounts. For example, they act as co-enzymes and cofactors in human system which play different roles in growth, metabolism and immune system development (Ogunkunle et al., 2014). As a result of toxic metals inherent from the consumption of fruits, especially fruits sold in an open market or at the roadside where exposure to vehicular emission is high, there is need to analyze these fruits to ensure that the levels of heavy metals constituents meet the international requirements.

This study was therefore carried out to estimate the levels of important heavy metals namely: lead, zinc, 
cadmium, chromium, copper and nickel in regularly consumed fruits (orange, carrot, cucumber, pineapple, watermelon) obtained in five different market locations in Lagos state, Nigeria.

\section{MATERIALS AND METHODS}

Study Area: The fruit samples were collected from five local government areas of Lagos State.

\begin{tabular}{|c|c|c|c|}
\hline $\mathbf{S} / \mathbf{N}$ & Market Location & Local Government Areas & Co-ordinates \\
\hline 1 & Oyingbo market & Lagos Mainland & Lat.6.48373 ${ }^{\circ} \mathrm{N}$ Long. $3.38892^{\circ} \mathrm{E}$ \\
\hline 2 & Iyana-ipaja & Alimosho & Lat.6.61781 ${ }^{\circ} \mathrm{N}$ Long. $3.29946^{\circ} \mathrm{E}$ \\
\hline 3 & Iyana-iba market & Ojo & Lat.6.48325 $\mathrm{N}$ Long. $3.19902^{\circ} \mathrm{E}$ \\
\hline 4 & Agboju market & Amuwo odofin & Lat.6.45957 $\mathrm{N}$ Long. $3.28639^{\circ} \mathrm{E}$ \\
\hline 5 & Ketu market & Ikosi/Isheri & Lat.6.59643 $\mathrm{N}$ Long. $3.38490^{\circ} \mathrm{E}$ \\
\hline
\end{tabular}

Specimen: The fruits used were: Cucumber (Cисиmis sativus); Carrot (Daucus carota); Pineapple (Ananas comosus); Orange (Citrus sinensis); Watermelon (Citrullus vulgaris)

Sample Processing: The samples were collected randomly in triplicates from markets in five local government areas of Lagos State, after which they were placed in glass petri dishes and dried in an oven at $35^{\circ} \mathrm{C}$. After 24 hours of drying, the lumps present were broken down with a clean glass rod in order to expose the inside for drying. When the samples appeared to be dried, they were left in the oven for another 24hours before grinding. After drying, the samples were then grinded using a mortar and pestle and then passed through a $2 \mathrm{~mm}$ sieve to remove any present impurities.

Extraction and Analysis: The particles in the sample were stored in polythene bags until required. $0.5 \mathrm{~g}$ of the fruit sample was weighed and transferred into a long Kjeldah flask and digested with $25 \mathrm{~cm}^{3}$ of $6 \mathrm{M}$ $\mathrm{HCl}, 5 \mathrm{~cm}^{3}$ of $69 \% \mathrm{HNO}_{3}$ and $0.5 \mathrm{~cm}^{3}$ of $98 \% \mathrm{H}_{2} \mathrm{SO}_{4}$ in that order. The solutions were mixed gently, swirled and placed on the electromantle at moderate temperature. The sample mixture was then allowed to boil for about 15 minutes while swirling gently at intervals so as to have a clear solution. The flask and its content were allowed to cool down after which $5 \mathrm{~cm}^{3}$ of hot distilled water was added and the mixture was allowed to boil, and finally filtered through a whatman No.40 filter paper into $50 \mathrm{ml}$ volumetric flask. Hot distilled water was used to wash down sample from filter paper into a volumetric flask; the sample solution (digested sample) was stored in a stock plastic bottle for instrumental analysis. This procedure was repeated for the entire fruits sample; a blank sample was prepared using the same procedure without any of the fruits sample. Replicate digestions were run on each samples and the filtrations were analyzed for $\mathrm{Pb}, \mathrm{Cr}, \mathrm{Cd}, \mathrm{Cu}, \mathrm{Zn}$ and $\mathrm{Ni}$ using Atomic Absorption spectrometer model 210/211 VGP at various wavelength for each metal $(\mathrm{Pb}=283.3, \mathrm{Cr}=$ 357.9, $\mathrm{Cd}=228.9, \mathrm{Cu}=324.7, \mathrm{Zn}=213.9$ and $\mathrm{Ni}=$ 341.5).

Statistical Analysis: The statistical significance in mean concentrations of heavy metals in the fruits derived from various market sites were tested using IBM SPSS version 20.0 and One Way analysis of variance (ANOVA). A probability level of $\mathrm{P}<0.05$ was considered statistically significant.

\section{RESULTS AND DISCUSSION}

Heavy metals affect the nutritive values of agricultural materials and also have deleterious effect on human beings. National and international regulations on food quality set the maximum permissible levels of toxic metals in human food; hence an increasingly important aspect of food quality should be to control the concentrations of heavy metals in food (Radwan and Salama, 2006) (Sobukola et al., 2008). In this study, the highest level of lead was found in carrot $(0.178 \mathrm{mg} / \mathrm{kg})$ while pineapple $(0.100 \mathrm{mg} / \mathrm{kg})$ had the lowest level of lead as shown in Table 2 . These results are comparable to those reported for watermelon $(0.108 \mathrm{mg} / \mathrm{kg})$, orange $(0.106 \mathrm{mg} / \mathrm{kg})$ and Pineapple $(0.128 \mathrm{mg} / \mathrm{kg})$ by Mohamed and Khairia (2012). The fruits from Iyana-Ipaja market had the highest level of lead $(0.186 \mathrm{mg} / \mathrm{kg})$ while the fruits from Oyingbo market had the lowest level of lead $(0.085 \mathrm{mg} / \mathrm{kg})$ as shown in Table 3 . The fruits in this study may have been affected by lead through pollutants in irrigation water, farm soil or due to pollution from the highways traffic (Mohamed and Khairia, 2012). Chromium is naturally occurring, it can be found in rocks, animals, plants, and soil and may be found in liquid, solid, or gas states, they are toxins and can cause irritation to the lungs if high level is inhaled. Chromium was observed to be low in all samples analyzed varying between 0.130 and 0.163 ; lowest in pineapple and highest in cucumber. These values are still within the safe limit of $0.2 \mathrm{mg} / \mathrm{kg}$ set by FAO/WHO (Ogunkunle et al., 2014). Cadmium is a non-essential element in 
foods and natural waters and it accumulates in the kidneys and liver (Divrikli et al., 2010). Cadmium is a very toxic metal; all soils and rocks, including coal and mineral fertilizers, contain some cadmium.

\begin{tabular}{lllllll}
\multicolumn{7}{c}{ Table 2: Heavy metals constituents in the fruit samples studied } \\
\hline Fruits & $\mathbf{P b}(\mathbf{m g} / \mathbf{k g}$ & $\begin{array}{l}\mathbf{C r} \\
\mathbf{( m g} / \mathbf{k g})\end{array}$ & $\begin{array}{l}\mathbf{C d} \\
\mathbf{( m g} / \mathbf{k g})\end{array}$ & $\begin{array}{l}\mathbf{C u} \\
(\mathbf{m g} / \mathbf{k g})\end{array}$ & $\begin{array}{l}\mathbf{Z n} \\
(\mathbf{m g} / \mathbf{k g})\end{array}$ & $\mathbf{N i}(\mathbf{m g} / \mathbf{k g})$ \\
\hline Carrot & $0.178 \mathrm{~b}$ & $0.141 \mathrm{ab}$ & $0.066 \mathrm{~b}$ & $0.279 \mathrm{bc}$ & $3.219 \mathrm{a}$ & $0.181 \mathrm{a}$ \\
Cucumber & $0.169 \mathrm{~b}$ & $0.163 \mathrm{~b}$ & $0.063 \mathrm{~b}$ & $0.317 \mathrm{~cd}$ & $3.657 \mathrm{ab}$ & $0.179 \mathrm{a}$ \\
Pineapple & $0.100 \mathrm{a}$ & $0.130 \mathrm{a}$ & $0.063 \mathrm{~b}$ & $0.262 \mathrm{~b}$ & $3.705 \mathrm{ab}$ & $0.178 \mathrm{a}$ \\
Watermelo & $0.131 \mathrm{a}$ & $0.143 \mathrm{ab}$ & $0.055 \mathrm{~b}$ & $0.358 \mathrm{~d}$ & $3.990 \mathrm{ab}$ & $0.197 \mathrm{a}$ \\
Orange & $0.149 \mathrm{a}$ & $0.139 \mathrm{ab}$ & $0.036 \mathrm{a}$ & $0.203 \mathrm{a}$ & $3.799 \mathrm{~b}$ & $0.140 \mathrm{a}$ \\
P-Value & 0.000 & $0.199^{*}$ & 0.011 & 0.000 & 0.028 & $0.423^{*}$
\end{tabular}

$\overline{\text { Means followed by the same letters are not significantly different; * } P \text {-value is not significant at } P>0.05}$

\begin{tabular}{|c|c|c|c|c|c|c|c|}
\hline Fruits & Location & $\mathbf{P b}$ & $\mathrm{Cr}$ & Cd & $\mathbf{C u}$ & $\mathbf{Z n}$ & $\mathbf{N i}$ \\
\hline & Unit & $(\mathrm{mg} / \mathrm{kg})$ & & & & & \\
\hline \multirow{5}{*}{ Carrot } & Oyingbo & $0.080 \mathrm{a}$ & $0.147 \mathrm{a}$ & $0.040 \mathrm{a}$ & $0.253 \mathrm{ab}$ & $2.200 \mathrm{a}$ & $0.023 \mathrm{a}$ \\
\hline & Iyana & $0.240 \mathrm{c}$ & $0.157 \mathrm{a}$ & $0.070 \mathrm{a}$ & $0.270 \mathrm{ab}$ & $3.320 \mathrm{~b}$ & $0.193 \mathrm{~b}$ \\
\hline & Iyana Iba & $0.127 \mathrm{~b}$ & $0.160 \mathrm{~b}$ & $0.080 \mathrm{a}$ & $0.350 \mathrm{~b}$ & $4.173 \mathrm{c}$ & $0.247 \mathrm{c}$ \\
\hline & Agboju & $0.220 \mathrm{c}$ & $0.120 \mathrm{a}$ & $0.080 \mathrm{a}$ & $0.230 \mathrm{a}$ & $2.833 \mathrm{a}$ & $0.220 \mathrm{c}$ \\
\hline & Ketu & $0.223 c$ & $0.120 \mathrm{a}$ & $0.060 \mathrm{a}$ & $0.290 \mathrm{ab}$ & $3.567 \mathrm{a}$ & $0.223 \mathrm{c}$ \\
\hline \multirow[t]{5}{*}{ Cucumber } & Oyingbo & $0.123 \mathrm{a}$ & $0.173 b$ & $0.030 \mathrm{a}$ & $0.260 \mathrm{a}$ & $3.260 \mathrm{a}$ & $0.070 \mathrm{a}$ \\
\hline & Iyana & $0.220 \mathrm{c}$ & $0.153 a$ & $0.030 \mathrm{a}$ & $0.360 \mathrm{c}$ & $3.633 a$ & $0.240 \mathrm{c}$ \\
\hline & Iyana Iba & $0.160 \mathrm{ab}$ & $0.190 \mathrm{~b}$ & $0.053 a$ & $0.360 \mathrm{c}$ & $3.783 b$ & $0.180 \mathrm{~b}$ \\
\hline & Ágboju & $0.173 b$ & $0.157 \mathrm{a}$ & $0.130 \mathrm{~b}$ & $0.333 b c$ & $3.333 \mathrm{a}$ & $0.160 \mathrm{~b}$ \\
\hline & Ketu & $0.167 \mathrm{ab}$ & $0.143 a$ & $0.073 a$ & $0.273 \mathrm{a}$ & $4.273 b$ & $0.243 c$ \\
\hline \multirow[t]{5}{*}{ Pineapple } & Oyingbo & $0.060 \mathrm{a}$ & $0.120 \mathrm{a}$ & $0.060 \mathrm{a}$ & $0.213 \mathrm{a}$ & $4.217 \mathrm{~b}$ & $0.033 \mathrm{a}$ \\
\hline & Iyana & $0.160 \mathrm{~b}$ & $0.120 \mathrm{a}$ & $0.060 \mathrm{a}$ & $0.240 \mathrm{a}$ & $4.127 \mathrm{~b}$ & $0.160 \mathrm{~b}$ \\
\hline & Iyana Iba & $0.087 \mathrm{a}$ & $0.127 \mathrm{a}$ & $0.080 \mathrm{a}$ & $0.250 \mathrm{ab}$ & $4.420 \mathrm{~b}$ & $0.263 \mathrm{c}$ \\
\hline & Agboju & $0.077 \mathrm{a}$ & $0.130 \mathrm{a}$ & $0.080 \mathrm{a}$ & $0.263 b$ & $2.530 \mathrm{a}$ & $0.253 \mathrm{c}$ \\
\hline & Ketu & $0.117 \mathrm{~b}$ & $0.133 a$ & $0.033 \mathrm{a}$ & $0.343 \mathrm{c}$ & $3.233 \mathrm{a}$ & $0.180 \mathrm{~b}$ \\
\hline \multirow{5}{*}{ Watermelo } & Oyingbo & $0.120 \mathrm{a}$ & $0.080 \mathrm{a}$ & $0.070 \mathrm{a}$ & $0.220 \mathrm{a}$ & $3.573 b$ & $0.047 \mathrm{a}$ \\
\hline & Iyana & $0.140 \mathrm{a}$ & $0.077 \mathrm{a}$ & $0.030 \mathrm{a}$ & $0.390 \mathrm{bc}$ & $3.123 \mathrm{a}$ & $0.230 \mathrm{c}$ \\
\hline & Iyana Iba & $0.127 \mathrm{a}$ & $0.223 \mathrm{c}$ & $0.043 a$ & $0.373 b$ & $5.100 \mathrm{~d}$ & $0.310 \mathrm{~d}$ \\
\hline & Ägboju & $0.130 \mathrm{a}$ & $0.170 \mathrm{~b}$ & $0.060 \mathrm{a}$ & $0.367 \mathrm{c}$ & $3.507 \mathrm{~b}$ & $0.120 \mathrm{~b}$ \\
\hline & Ketu & $0.120 \mathrm{a}$ & $0.163 b$ & $0.070 \mathrm{a}$ & $0.440 \mathrm{c}$ & $4.647 \mathrm{c}$ & $0.277 \mathrm{c}$ \\
\hline \multirow[t]{5}{*}{ Orange } & Oyingbo & $0.040 \mathrm{a}$ & $0.230 \mathrm{c}$ & $0.050 \mathrm{a}$ & $0.140 \mathrm{a}$ & $4.150 \mathrm{c}$ & $0.060 \mathrm{a}$ \\
\hline & Iyana & $0.170 \mathrm{~b}$ & $0.127 \mathrm{~b}$ & $0.003 \mathrm{a}$ & $0.230 \mathrm{~b}$ & $4.420 \mathrm{c}$ & $0.130 \mathrm{~b}$ \\
\hline & Iyana Iba & $0.180 \mathrm{~b}$ & $0.123 b$ & $0.020 \mathrm{a}$ & $0.113 \mathrm{a}$ & $3.620 \mathrm{~b}$ & $0.120 \mathrm{~b}$ \\
\hline & Agboju & $0.047 \mathrm{a}$ & $0.090 \mathrm{a}$ & $0.050 \mathrm{a}$ & $0.180 \mathrm{ab}$ & $2.933 \mathrm{a}$ & $0.240 \mathrm{c}$ \\
\hline & Ketu & $0.217 \mathrm{c}$ & $0.127 \mathrm{~b}$ & $0.057 \mathrm{a}$ & $0.350 \mathrm{c}$ & $3.873 \mathrm{~b}$ & $0.150 \mathrm{~b}$ \\
\hline
\end{tabular}

Means followed by the same letters are not significantly different

\begin{tabular}{|c|c|c|c|c|c|}
\hline \multirow{2}{*}{$\begin{array}{l}\text { Heavy Metals } \\
\text { Mean(mg/kg) }\end{array}$} & \multicolumn{5}{|c|}{ Markets } \\
\hline & Oyingbo & Iyana Ipaja & Iyana Iba & Agboju & Ketu \\
\hline Lead & 0.085 & 0.186 & 0.151 & 0.129 & 0.169 \\
\hline Chromium & 0.150 & 0.127 & 0.177 & 0.133 & 0.137 \\
\hline Cadmium & 0.050 & 0.039 & 0.050 & 0.080 & 0.059 \\
\hline Copper & 0.217 & 0.298 & 0.311 & 0.275 & 0.339 \\
\hline Zinc & 3.480 & 3.725 & 4.092 & 3.027 & 3.919 \\
\hline Nickel & 0.048 & 0.191 & 0.207 & 0.199 & 0.215 \\
\hline
\end{tabular}

\begin{tabular}{lllllll}
\multicolumn{7}{c}{ Table 5: Proximate analysis of the fruits collected } \\
\hline Fruit & $\begin{array}{l}\text { Crude } \\
\text { Protein (\%) }\end{array}$ & $\begin{array}{l}\text { Crude } \\
\text { fat }(\%)\end{array}$ & $\begin{array}{l}\text { Crude } \\
\text { fibre (\%) }\end{array}$ & $\begin{array}{l}\text { Ash } \\
(\%)\end{array}$ & $\begin{array}{l}\text { Moisture } \\
(\boldsymbol{\%})\end{array}$ & $\begin{array}{l}\text { Carbohydrate } \\
(\%)\end{array}$ \\
\hline Carrot & $1.138 \mathrm{~d}$ & $0.433 \mathrm{~b}$ & $1.385 \mathrm{c}$ & 1.59 & $88.237 \mathrm{c}$ & $8.599 \mathrm{~b}$ \\
Cucumber & $0.888 \mathrm{c}$ & $0.262 \mathrm{ab}$ & $1.047 \mathrm{c}$ & 1.75 & $86.985 \mathrm{~b}$ & $10.115 \mathrm{~d}$ \\
Pineapple & $0.538 \mathrm{a}$ & $0.153 \mathrm{a}$ & $0.611 \mathrm{~b}$ & 0.41 & $86.842 \mathrm{a}$ & $12.049 \mathrm{e}$ \\
Watermelo & $0.651 \mathrm{~b}$ & $0.113 \mathrm{a}$ & $0.490 \mathrm{a}$ & 0.35 & $91.308 \mathrm{e}$ & $7.571 \mathrm{a}$ \\
Orange & $0.699 \mathrm{~b}$ & $0.429 \mathrm{~b}$ & $0.619 \mathrm{~b}$ & 0.54 & $88.425 \mathrm{~d}$ & $9.583 \mathrm{c}$ \\
P-Value & $0.000^{*}$ & $0.000^{*}$ & $0.000^{*}$ & 0.00 & $0.000^{*}$ & $0.000^{*}$ \\
\hline
\end{tabular}

Means followed by the same letters are not significantly different; *P-value is significant at $\mathrm{P}<0.05$. 
Cadmium is used in the production of various things such as batteries, pigments, metal coatings, and plastics; it is also used extensively in electroplating. The levels of cadmium was observed to be low in all the fruits analyzed, orange being the lowest $(0.003 \mathrm{mg} / \mathrm{kg})$ and cucumber being the highest $(0.130 \mathrm{mg} / \mathrm{kg})$. Cadmium level was observed to be highest among fruits analyzed from Agboju market $(0.083 \mathrm{mg} / \mathrm{kg})$ and lowest among the fruits from IyanaIpaja market $(0.039 \mathrm{mg} / \mathrm{kg})$. Various values have been previously reported; watermelon (0.02 and 0.0004 $\mathrm{mg} / \mathrm{kg})$; orange $(0.04$ and $0.0009 \mathrm{mg} / \mathrm{kg}$ ) and banana $(0.02$ and $0.001 \mathrm{mg} / \mathrm{kg})$ by (Sobukola et al., 2008) and (Jassir et al., 2005) respectively. However, (Onianwe et al., 2001) reported 0.003 and $0.09 \mathrm{mg} / \mathrm{kg}$ in pawpaw and in fluted pumpkin plant respectively. The varying concentrations of cadmium may be due to the fact that fruits have different capacities for absorbing metals. However, cadmium concentration of all the fruits in all the locations was found to be within the safe limit of WHO/FAO. $\mathrm{Zn}$ is an essential element in human diet as it is required to maintain normal growth and development, also for the functioning of the immune system (D'Mello, 2003).

Table 6: Summary of results for heavy metals and the proximate composition for the five markets and study area (mean \pm standard

\begin{tabular}{|c|c|c|}
\hline Fruits & $\begin{array}{l}\text { Heavy } \\
\text { Metals }\end{array}$ & $\begin{array}{l}\text { Mean } \pm \text { Standard } \\
\text { Deviation }\end{array}$ \\
\hline \multirow[t]{6}{*}{ CARROT } & $\mathrm{Pb}$ & $0.18 \pm 0.7$ \\
\hline & $\mathrm{Cr}$ & $0.14 \pm 0.00$ \\
\hline & $\mathrm{Cd}$ & $0.07 \pm 0.0$ \\
\hline & $\mathrm{Cu}$ & $0.28 \pm 0.0$ \\
\hline & $\mathrm{Zn}$ & $3.22 \pm 0.7$ \\
\hline & $\mathrm{Ni}$ & $0.18 \pm 0.1$ \\
\hline \multirow[t]{6}{*}{ CUCUMBER } & $\mathrm{Pb}$ & $0.17 \pm 0.0$ \\
\hline & $\mathrm{Cr}$ & $0.16 \pm 0.0$ \\
\hline & $\mathrm{Cd}$ & $0.06 \pm 0.0$ \\
\hline & $\mathrm{Cu}$ & $0.32 \pm 0.0$ \\
\hline & $\mathrm{Zn}$ & $3.66 \pm 0.4$ \\
\hline & $\mathrm{Ni}$ & $0.18 \pm 0.0$ \\
\hline \multirow[t]{6}{*}{ PINEAPPLE } & $\mathrm{Pb}$ & $0.10 \pm 0.0$ \\
\hline & $\mathrm{Cr}$ & $0.13 \pm 0.0$ \\
\hline & $\mathrm{Cd}$ & $0.06 \pm 0.0$ \\
\hline & $\mathrm{Cu}$ & $0.26 \pm 0.0$ \\
\hline & $\mathrm{Zn}$ & $3.71 \pm 0.8$ \\
\hline & $\mathrm{Ni}$ & $0.18 \pm 0.1$ \\
\hline \multirow[t]{6}{*}{ WATERMELON } & $\mathrm{Pb}$ & $0.13 \pm 0.0$ \\
\hline & $\mathrm{Cr}$ & $0.14 \pm 0.1$ \\
\hline & $\mathrm{Cd}$ & $0.05 \pm 0.0$ \\
\hline & $\mathrm{Cu}$ & $0.36 \pm 0.1$ \\
\hline & $\mathrm{Zn}$ & $3.99 \pm 0.8$ \\
\hline & $\mathrm{Ni}$ & $0.20 \pm 0.1$ \\
\hline \multirow[t]{6}{*}{ ORANGE } & $\mathrm{Pb}$ & $0.13 \pm 0.1$ \\
\hline & $\mathrm{Cr}$ & $0.14 \pm 0.1$ \\
\hline & $\mathrm{Cd}$ & $0.04 \pm 0.0$ \\
\hline & $\mathrm{Cu}$ & $0.20 \pm 0.1$ \\
\hline & $\mathrm{Zn}$ & $3.8 \pm 0.6$ \\
\hline & $\mathrm{Ni}$ & $0.14 \pm 0.1$ \\
\hline
\end{tabular}

ROTIMI, OT; OGUNYEBI, AL; FINGESI, TS
Zn deficiency in the diet may be highly detrimental to human health than too much of $\mathrm{Zn}$ in the diet. The Agency for Toxic Substances and Disease Registry recommended dietary allowance for $\mathrm{Zn}$ is $15 \mathrm{mg} / \mathrm{day}$ for men and $12 \mathrm{mg} / \mathrm{day}$ for women (Divrikli et al., 2010), but high concentration of $\mathrm{Zn}$ in fruits may cause vomiting, renal damage, cramps etc. In this study of the concentration of heavy metals, Zinc had the highest concentration $(5.100 \mathrm{mg} / \mathrm{kg})$ in water melon from Iyana iba market; while orange, pineapple, cucumber had a descending order of concentration and lastly, carrot had the least zinc content $(2.200 \mathrm{mg} / \mathrm{kg})$ from Oyingbo market as shown in Table 2. The high level of zinc reported in this study shows that it is comparable to those reported by (Karavoltsos et al., 2002) who also reported $\mathrm{Zn}$ levels ranging from 5.35 and $7.40 \mathrm{mg} / \mathrm{kg} ; 2.38$ and $2.20 \mathrm{mg} / \mathrm{kg}$; as well as 5.59 and $1.50 \mathrm{mg} / \mathrm{kg}$ for watermelon, orange and banana, respectively (Khairiah et al., 2004). This study shows that the concentrations of copper in all the fruits from all locations ranged between $0.113-0.440 \mathrm{mg} / \mathrm{kg}$; orange had the least copper content while watermelon had the highest copper content. The results obtained here were observed to be lower compared to other published results (Xiao-Dong et al., 2016) reported $1.47 \mathrm{mg} / \mathrm{kg}$ for apple. Furthermore, 1.22 and 2.13 $\mathrm{mg} / \mathrm{kg}, 1.27$ and $2.13 \mathrm{mg} / \mathrm{kg}$ and 2.51 , and $0.95 \mathrm{mg} / \mathrm{kg}$ have been reported for the concentration of $\mathrm{Cu}$ in watermelon, orange and banana by (Ogunkunle et al., 2014) and (Grembecka and Szefer, 2013) respectively. Investigation from this study shows that the values of $\mathrm{Cu}$ content in the fruits from all the locations were found within safe limits $(73 \mathrm{mg} / \mathrm{kg})$ in all the samples as described by WHO standards. Nickel occurs more naturally in plants than in animal flesh. It plays some role in body system such as the activation of some enzyme systems in trace amount, but its toxicity at higher levels is more prominent (D'Mello, 2003). The $\mathrm{Ni}$ levels in the samples tested varied between $0.023 \mathrm{mg} / \mathrm{kg}$ and $0.310 \mathrm{mg} / \mathrm{kg}$ with the lowest observed in carrot and highest observed in watermelon. The fruits from Ketu market had the highest mean concentration of $\mathrm{Ni}(0.215 \mathrm{mg} / \mathrm{kg})$. However, Ni level of $0.067 \mathrm{mg} / \mathrm{kg}$ for Indian Basil have been reported by (Elbagermi et al., 2012) which is within the range of values obtained from this study. Proximate analysis (Table 4) indicated significant variability in the constituents contained in the fruits studied. Moisture content was the highest constituent contained in all the fruits followed by carbohydrate while crude fat was the least contained in all the fruits. The highest moisture content was found in watermelon $(91.3 \%$ ) while the least was found in pineapple $(86.84 \%)$. Crude protein was highest in carrot $(1.138 \%)$ and least in pineapple $(0.538 \%)$. Watermelon had the least crude fat $(0.113 \%)$ moisture content was the highest constituent 
observed being highest in watermelon and lowest in pineapple. Carbohydrate is the next highest constituent after moisture, highest in pineapple and lowest in watermelon. It was observed that crude fat had the lowest constituent in the fruits analyzed; lowest in watermelon and highest in carrot.

Conclusion: In conclusion, there is need for continuous monitoring of heavy metals and proximate analysis in fruits because, fruits are the main sources of food supplements for humans in many parts of the world and are considered as bio-indicators of environmental pollution.

\section{REFERENCES}

Abbas, M; Parveen, Z; Iqbal, S; Ahmed, M; Bhutto, R (2010). Monitoring of toxic metals (cadmium, lead, arsenic and mecury) in vegetables of Sindh, Pakistan. Kathmandu University J. Sci., Engineer. Technol. 6(2): 60-65.

Divrikli, U; Horzum, N; Soylak, M; Elci, L (2006). Trace heavy metal contents of some spices and herbal plants from western Anatolia, Turkey. Inter. J. Food Sci. Technol. 41:712-716.

D'Mello, JPF (2003). Food safety: Contamination and Toxins. CABI Publishing, Wallingford, United Kingdom. 480pp.

Elbagermi, MA; Edwards, HG; Alajtal, AI (2012). Monitoring of Heavy Metal Content in Fruits and Vegetables Collected from Production and Market Sites in the Misurata Area of Libya. Anal. Chem. 5pp.

Grembecka, M; Szefer, P (2013). Comparative assessment of essential and heavy metals in fruits from different geographical region. Environ. Monit. Assess. 185(11): 9139-9160.

Jassir, MS; Shaker, A; Khaliq, MA (2005). Deposition of heavy metals on green leafy vegetables sold on roadsides of Riyadh city, Saudi Arabia. Bull. Environ. Contam. Toxicol. 75:1020-1027.

Karavoltsos, S; Sakellari, A; Dimopoulos, M; Dssenakis, M; Scoullos, M (2002). Cadmium content if foodstuffs from Greek market. Food Add. Contaminants. 19(10): 954-962.

Khairiah, T; Zalifah, MK; Yin, YH; Aminah, A (2004). The uptake of heavy metals by fruit type vegetables grown in selected agricultural areas. Pakistan J. Biologic. Sci. 7:1438-1442.
Mausi, G; Simiyu, G; Lutta, S (2014). Assessment of Selected Heavy Metal Concentrations in Selected Fresh Fruits in Eldoret Town, Kenya. J. Environ. Earth Sci. 4(3): 1-8

Mohamed, HH; Khairia, MA (2012). Assessment of some heavy metals in vegetables, cereals and fruits in Saudi Arabian markets. The Egyptian J. Aquatic Res. 38 (1): 3-37

Ogunkunle, AT; Bello, OS; Ojofeitimi, OS (2014). Determination of heavy metal contamination of street-vended fruits and vegetables in Lagos state, Nigeria. Inter. Food Res. J.. 21(5): 1725-1730.

Onianwe, PC; Lawal, JA; Ogunkeye, AA; Orejimi, BM (2001). Cadmium and Nickel compositions of some Nigerian Foods. J. Food Composite. Analyst. 13: 961-969.

Pasha, Q; Malik, SA; Shaheen, N; Shah MH (2010). Comparison of Trace Elements in the scalp Hair of Malignant and Benign Breast Lesions Versus Healthy Women. Biol Trace Elem Res. 134(2):16073.

Qui, XX; Huang, DF; Cai, SX; Chen, F; Ren, ZG; Cai, YC (2000). Investigations on vegetables pollution and pollution sources and its control in Fuzhou, Fujian Province. Fujian J. Agric. Sci. 15:16-21.

Radwan, MA; Salama, AK (2006). Market basket survey for some heavy metals in Egyptian fruits and vegetables. Food Chem. Toxicol. 44:1273-1278.

Sobukola, OP; Awonorin, SO; Idowu, MA; Bamiro, FO (2008). Chemical and physical hazard profile of 'robo' processing - a street vended melon snack. Inter. J. Food Sci. Technol. 43(2): 237-242.

Sobukola, OP; Adeniran, OM; Odedairo, AA; Kajihausa, OE. (2010). Heavy metal levels of some fruits and leafy vegetables from selected markets in Lagos, Nigeria. Afr. J. Food Sci. 4(2): 389-393.

World Health Organization (2012). Evaluation of certain food additives and contaminants (41st Report of the Joint FAO/WHO Expert Committee on Food Additives). World Health Organization Technical Report Series No. 837.

Xiao-Dong, P; Ping-Gu, W; Xian-Gen, J (2016). Levels and potential health risk of heavy metals in marketed vegetables in Zhejiang, China. Sci. Reports 6. Doi: 10.1038/srep20317. 